\title{
Existence and Uniqueness with Ulam Stability study of the solution for a class of Caputo fractional integro-differential equation with mixed conditions
}

\author{
ABDELLOUAHAB Naimi ${ }^{1}$ \\ ${ }^{1}$ Kasdi Merbah Ouargla University Faculty of Mathematics and Materials Science
}

January 22, 2021

\begin{abstract}
In this article we show the existence, uniqueness and Ulam stability results of the solution for a class of a nonlinear Caputo fractional integro-differential problem with mixed conditions. we use three fixed point theorems to proof the existence and uniqueness results. By the results obtained, the reasons for the Ulam stability are verified. An example proposed to illustrate our main results.
\end{abstract}

\section{Hosted file}

Naimi04.pdf available at https://authorea.com/users/391171/articles/505346-existence-anduniqueness-with-ulam-stability-study-of-the-solution-for-a-class-of-caputo-fractionalintegro-differential-equation-with-mixed-conditions

\section{Hosted file}

Naimi04.tex available at https://authorea.com/users/391171/articles/505346-existence-anduniqueness-with-ulam-stability-study-of-the-solution-for-a-class-of-caputo-fractionalintegro-differential-equation-with-mixed-conditions 